\title{
Effects of the Novel Acetylcholinesterase Inhibitor SDZ ENA 713 on Sleep in Man
}

\author{
Edith Holsboer-Trachsler, M.D., Martin Hatzinger, M.D., Rudolf Stohler, M.D., \\ Ulich Hemmeter, M.D., Julian Gray, M.D., Jürgen Müller, M.D., Ralph Kocher, M.D., \\ and René Spiegel, Ph.D.
}

A novel brain-selective acetylcholinesterase inhibitor, SDZ ENA 713, is under development for the treatment of dementia of the Alzheimer type. To determine the threshold dose for central activity, single doses of the compound were administered to 20 young male oolunteers in a double-blind cross-over design and the effects on the sleep electroencephalography studied. The first group of eight volunteers received in random order: placebo, $0.5 \mathrm{mg}$; and $1 \mathrm{mg}$ SDZ ENA 713. The second group of 12 volunteers received: placebo, $1.3 \mathrm{mg}$; and 2 mg SDZ ENA 713. Sleep quality was not affected by the study medication, which was well tolerated by all subjects. A statistically significant increase in rapid-eye movement sleep density was observed after doses of $1 \mathrm{mg}$, $1.3 \mathrm{mg}$, and $2 \mathrm{mg}$. Rapid-eye movement latency and slow-wave sleep were not altered. The results demonstrate that SDZ ENA 713 is centrally active in man at well-tolerated doses. [Neuropsychopharmacology 8:87-92, 1993]
KEY wORDS: SDZ ENA 713; Acetylcholinesterase inhibitor; Dementia; Sleep

The drug SDZ ENA 713 is an acetylcholinesterase (AChE) inhibitor being developed for the symptomatic treatment of dementia of the Alzheimer type. In animal studies SDZ ENA 713 shows a selectivity for brain $\mathrm{AChE}$ compared with that in the periphery. Furthermore, at a given dose AChE inhibition is more pronounced in the rat cortex and hippocampus than in the corpus striatum and brain stem. The drug SDZ ENA 713 synchronizes hippocampal theta waves in the rat electroencephalogram (EEG) that reflect an increase of muscarinic activity in the hippocampus (Enz et al. 1989).

From the Psychiatric University Clinic (EH-T, MH, RS, UH, JM PK), and CNS Clinical Research (JG, RS), Sandoz Pharma AG, Basel, Switzerland.

Address reprint requests to: Edith Holsboer-Trachsler, M.D., Department of Psychiatry, University of Basel, Wilhelm-Klein-Strasse $\eta$, 4025 Basel, Switzerland.

Received October 9, 1991; revised January 23, 1992 and March 4, 1992; accepted March 13, 1992.
A number of polygraphic sleep studies have shown that cholinergic agents facilitate rapid-eye movement (REM) sleep in man (Shiromani et al. 1987), possibly via M2 receptors (Velazquez-Moctezuma et al. 1989). The classic AChE inhibitor physostigmine and other cholinomimetic substances have been studied in this regard. Intravenous administration of physostigmine accelerated the onset of the first REM phase (Sitaram et al. 1976). A similar shortening of REM latency in healthy volunteers has been observed after administration of the muscarinic agonists arecoline (Sitaram et al. 1978) and pilocarpine (Berkowitz et al. 1990). Rapideye movement density was not altered after these agents. Another experimental muscarinic agonist, RS 86 , has been shown to induce marked shortening of REM latency in normal volunteers (Spiegel 1984). This effect was also present in patients with major depression, with an increase in the density of REMsleep (Lauer et al. 1989).

The purpose of the current study was to determine whether similar effects on REM sleep could be observed in man after well-tolerated single oral doses of SDZ ENA 713 and to determine the threshold dose for such effects. 


\section{METHODS}

\section{Subjects}

Twenty healthy male subjects aged 18 to 40 years were studied in two groups. After a general medical examination, including an electrocardiogram (ECG), laboratory tests, and a psychiatric interview, they were found to be physically and mentally healthy. They were free of drugs, including drugs of abuse and without personal or family history of any psychiatric illness. The volunteers gave written informed consent prior to entering the trial and were paid for their participation. The research protocol was approved by the local ethical committee.

\section{Design}

All subjects spent 5 nights in the sleep laboratory. The first 2 nights were adaptation nights, on which the subjects were administered placebo under single-blind conditions. On the subsequent 3 nights at 2200 hours each of the subjects in Group I took either a capsule of placebo, $0.5 \mathrm{mg}$ SDZ ENA 713, or $1 \mathrm{mg}$ SDZ ENA 713 under randomized double-blind conditions. Each of the twelve subjects in Group II took either a capsule of placebo, $1.3 \mathrm{mg}$ SDZ ENA 713, or $2 \mathrm{mg}$ SDZ ENA 713. $A$ randomized balanced cross-over design was used.

\section{Sleep}

Sleep was recorded between 2300 hours and 0700 hours by means of standard procedures: horizontal electrooculogram (EOG), submental electromyogram, EEG (C3-A2; C4-A1; C3-C4), and ECG. Respiratory movements were also monitored, using a belt incorporating a transducer ("Atemaufnehmer": ZAK, Simbach, Germany).

The records were scored under blind conditions by two experienced raters according to standardized criteria (Rechtschaffen and Kales 1968). The sleep parameters were analyzed according to the definitions in the standard program described by Lauer (1988). The following sleep parameters were determined.

Sleep Continuity Measures. Measures were taken of total sleep time ([TST] time in bed minus wake time), sleep period time ([SPT] time between sleep onset and final morning awakening), sleep efficiency (the ratio of TST to time in bed), sleep onset latency (time from "lights off" to the occurrence of the furst epoch of sleep stage 2), and intermittent time awake (in minutes).

Sleep Architecture Measure. Stage 1, 2, slow-wave sleep (stage 3 and 4), and REM (expressed in percent of SPT) were measured.

REM Sleep Measures. Measures were taken of REM latency (time from sleep onset to the first occurrence of REM stage), and REM density (the ratio of 3-second miniepochs per REM period including at least one REM to the total amount of all 3-second miniepochs per REM period). In addition, we calculated the REM densities for the first, second, and third thirds of the night as well as for the first, second, and third sleep cycle. Finally, we computed the ratio of the REM and non-REM period duration within each sleep cycle.

For evaluation of subjective sleep quality, after each night all subjects completed a questionnaire concerning their subjective impression of the previous night's sleep.

\section{Safety Data}

A full medical examination including ECG and labora. tory values was performed before and after the study. Vital signs were measured before and on the morning after each dose of medication.

\section{Statistical Analysis}

Background and safety data were quality controlled and entered into a computerized data bank. No statistical comparisons between the two groups were made with regard to these data. Sleep parameters were enterd into a separate computer database. Sleep parameters for the different treatments were compared by one-wap analysis of variance for repeated measures, (2 degres of freedom for treatment effects in each group).

\section{RESULTS}

\section{Effects of SDZ ENA 713 on Sleep}

Table 1 shows results for the variables of sleep cor tinuity and sleep architecture for the whole sample comparing placebo and drug conditions. In Group I twa subjects were excluded from analysis, one becaused consistently poor sleep and one because of a 1-hour de lay in drug intake on 1 night.

REM Measures. The changes in REM measures are summarized in Table 2. In Group I there was significant increase in REM density in the second cyct of the night after the $1 \mathrm{mg}$, but not the $0.5 \mathrm{mg}$, dose

In Group II, an increase in REM density compare with placebo was observed after both the $1.3 \mathrm{mg}$ and $2 \mathrm{mg}$ dose (Fig. 1). The increase in REM density wo significant in the first and second thirds of the nighte No significant difference between REM latencies ars duration of REM sleep on active and placebo medice tion were observed in either group.

Sleep Continuity. A significant decrease in sleep etit 
Table 1. Effects of SDZ-ENA 713: Sleep Continuity and Architecture ${ }^{a}$

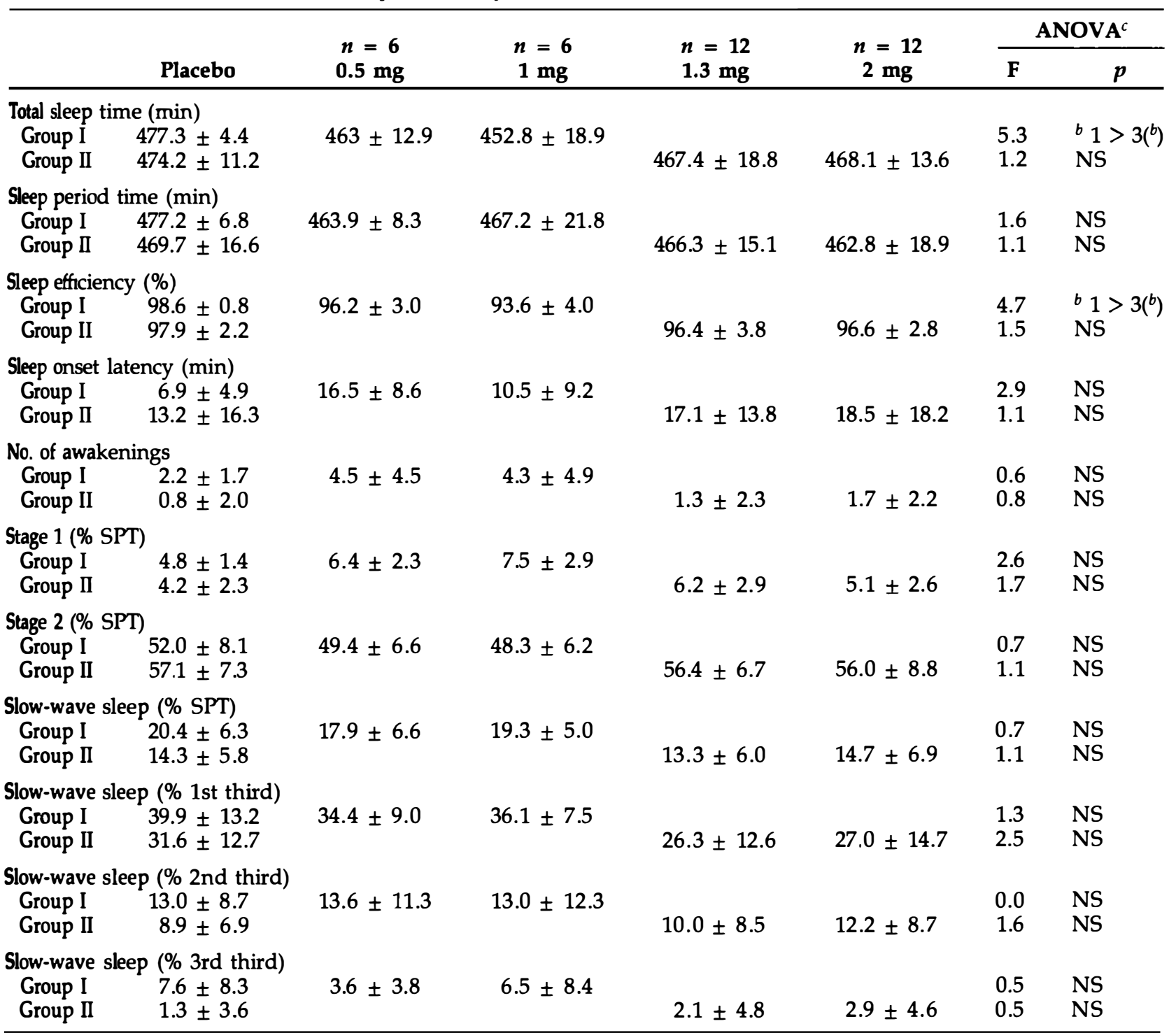

Data presented are mean \pm SD.

$0<0.05$.

( Pair comparisons (Fisher) if ANOVA significant.

Subj. No. 1-8: Placebo $0.5 \mathrm{mg}-1 \mathrm{mg}$; Subj. No. 5: drop out; without Subj. No. 3; Subj. No. 9-20: Placebo $1.3 \mathrm{mg}-2 \mathrm{mg}$.

ciency and TST were observed after the $1 \mathrm{mg}$ dose (Table 1).

Sleep Architecture. There were no significant effects of SDZ ENA 713 on other sleep parameters, including on slow-wave sleep and REM sleep percentages.

No evidence for carry-over effects from 1 night to the following was observed with regard to any sleep parameters (data not shown). Concerning subjective sleep quality, there was no evidence of a subjective alteration of sleep at any dose level from the sleep questionnaire. Four of the twelve subjects in Group II reported having more dreams than usual after the $2 \mathrm{mg}$ dose, compared with one subject after placebo administration.

\section{Safety Data}

There were no significant changes in safety parameters during the study. No adverse effects occurred, except for inflammation and edema of the skin around the electrodes in one subject.

There was no evidence for a change in respiratory or ventricular rate after any of the doses of SDZ ENA 713 in comparison with placebo. 
Table 2. Effects of SDZ-ENA 713: REM Sleep ${ }^{a}$

\begin{tabular}{|c|c|c|c|c|c|c|c|}
\hline \multirow{2}{*}{\multicolumn{2}{|c|}{ Placebo }} & \multirow{2}{*}{$\begin{array}{c}n=6 \\
0.5 \mathrm{mg}\end{array}$} & \multirow{2}{*}{$\begin{array}{c}n=6 \\
1 \mathrm{mg}\end{array}$} & \multirow{2}{*}{$\begin{array}{l}n=12 \\
1.3 \mathrm{mg}\end{array}$} & \multirow{2}{*}{$\begin{array}{c}n=12 \\
2 \mathrm{mg}\end{array}$} & \multicolumn{2}{|r|}{ ANOVA $^{d}$} \\
\hline & & & & & & $\mathbf{F}$ & $p$ \\
\hline $\begin{array}{l}\text { REM latenc } \\
\text { Group I } \\
\text { Group II }\end{array}$ & $\begin{array}{l}\min ) \\
70.1 \pm 15.0 \\
67.3 \pm 31.1\end{array}$ & $57.8 \pm 8.5$ & $75.1 \pm 37.0$ & $66.6 \pm 19.6$ & $68.2 \pm 26.0$ & $\begin{array}{l}0.8 \\
0.0\end{array}$ & $\begin{array}{l}\text { NS } \\
\text { NS }\end{array}$ \\
\hline $\begin{array}{c}\text { REM (\% SP } \\
\text { Group I } \\
\text { Group II }\end{array}$ & $\begin{array}{l}21.0 \pm 3.9 \\
23.8 \pm 5.2\end{array}$ & $23.3 \pm 4.4$ & $19.7 \pm 3.8$ & $23.1 \pm 3.2$ & $23.5 \pm 4.0$ & $\begin{array}{l}1.3 \\
0.1\end{array}$ & $\begin{array}{l}\text { NS } \\
\text { NS }\end{array}$ \\
\hline $\begin{array}{c}\text { REM densit } \\
\text { Group I } \\
\text { Group II }\end{array}$ & $\begin{array}{l}\text { total } \\
\qquad \begin{array}{l}2.5 \pm 0.5 \\
2.3 \pm 0.6\end{array}\end{array}$ & $2.5 \pm 0.6$ & $2.6 \pm 0.6$ & $2.8 \pm 0.7$ & $2.7 \pm 0.8$ & $\begin{array}{l}0.3 \\
6.9\end{array}$ & $\begin{array}{l}\text { NS } \\
{ }^{c} 1<4\left({ }^{b}\right), 1<5\left({ }^{(b)}\right)\end{array}$ \\
\hline $\begin{array}{l}\text { REM densit } \\
\text { Group I } \\
\text { Group II }\end{array}$ & $\begin{array}{l}\text { (1st third) } \\
1.8 \pm 0.8 \\
1.4 \pm 0.6\end{array}$ & $2.0 \pm 0.8$ & $2.8 \pm 1.2$ & $2.1 \pm 0.9$ & $2.1 \pm 0.9$ & $\begin{array}{l}1.7 \\
6.5\end{array}$ & $\begin{array}{l}\text { NS } \\
{ }^{c} 1<4\left({ }^{b}\right), 1<5\left(^{b}\right)\end{array}$ \\
\hline $\begin{array}{l}\text { REM densit } \\
\text { Group I } \\
\text { Group II }\end{array}$ & $\begin{array}{c}\text { (2nd third) } \\
2.5 \pm 0.5 \\
2.3 \pm 0.9\end{array}$ & $2.7 \pm 1.0$ & $2.1 \pm 1.2$ & $2.9 \pm 0.8$ & $2.9 \pm 0.9$ & $\begin{array}{l}1.1 \\
4.3\end{array}$ & $\begin{array}{l}\text { NS } \\
{ }_{b} 1<4(b), 1<5(\eta)\end{array}$ \\
\hline $\begin{array}{c}\text { REM densit } \\
\text { Group I } \\
\text { Group II }\end{array}$ & $\begin{array}{l}\text { (3rd third) } \\
2.7 \pm 0.8 \\
2.5 \pm 0.7\end{array}$ & $2.5 \pm 0.7$ & $2.8 \pm 0.8$ & $2.8 \pm 0.6$ & $2.7 \pm 0.9$ & $\begin{array}{l}0.3 \\
1.4\end{array}$ & $\begin{array}{l}\text { NS } \\
\text { NS }\end{array}$ \\
\hline $\begin{array}{l}\text { REM densit } \\
\text { Group I } \\
\text { Group II }\end{array}$ & $\begin{array}{l}\text { cycle } 1 \\
\qquad 1.6 \pm 0.7 \\
1.3 \pm 0.7\end{array}$ & $1.8 \pm 0.9$ & $2.1 \pm 0.6$ & $1.6 \pm 1.0$ & $1.8 \pm 1.0$ & $\begin{array}{l}0.8 \\
1.9\end{array}$ & $\begin{array}{l}\text { NS } \\
\text { NS }\end{array}$ \\
\hline $\begin{array}{l}\text { REM densit } \\
\text { Group I } \\
\text { Group II }\end{array}$ & $\begin{array}{l}\text { cycle } 2 \\
2.3 \pm 0.7 \\
1.9 \pm 0.9\end{array}$ & $2.2 \pm 0.6$ & $2.7 \pm 0.5$ & $2.7 \pm 0.9$ & $2.5 \pm 1.2$ & $\begin{array}{l}5.8 \\
2.0\end{array}$ & $\begin{array}{l}b 1<3(b), 2<3\left({ }^{b}\right) \\
\text { NS }\end{array}$ \\
\hline $\begin{array}{l}\text { REM densit } \\
\text { Group I } \\
\text { Group II }\end{array}$ & $\begin{array}{l}\text { cycle } 3 \\
\qquad 2.7 \pm 0.6 \\
2.3 \pm 1.1\end{array}$ & $2.5 \pm 1.1$ & $2.4 \pm 0.8$ & $3.0 \pm 1.2$ & $2.5 \pm 1.0$ & $\begin{array}{l}0.4 \\
1.9\end{array}$ & $\begin{array}{l}\text { NS } \\
\text { NS }\end{array}$ \\
\hline $\begin{array}{c}\text { REM/NREM } \\
\text { Group I } \\
\text { Group II }\end{array}$ & $\begin{array}{l}\text { ycle } 1 \\
0.1 \pm 0.1 \\
2.6 \pm 8.3\end{array}$ & $0.2 \pm 0.2$ & $0.2 \pm 0.1$ & $0.2 \pm 0.2$ & $1.7 \pm 5.0$ & $\begin{array}{l}1.7 \\
1.0\end{array}$ & $\begin{array}{l}\text { NS } \\
\text { NS }\end{array}$ \\
\hline $\begin{array}{l}\text { REM/NREM } \\
\text { Group I } \\
\text { Group II }\end{array}$ & $\begin{array}{l}\text { ycle } 2 \\
0.3 \pm 0.1 \\
0.3 \pm 0.1\end{array}$ & $0.4 \pm 0.1$ & $0.3 \pm 0.1$ & $0.3 \pm 0.1$ & $0.3 \pm 0.1$ & $\begin{array}{l}0.3 \\
0.4\end{array}$ & $\begin{array}{l}\text { NS } \\
\text { NS }\end{array}$ \\
\hline $\begin{array}{l}\text { REM/NREN } \\
\text { Group I } \\
\text { Group II }\end{array}$ & $\begin{array}{l}\text { ycle } 3 \\
0.2 \pm 0.2 \\
0.4 \pm 0.3\end{array}$ & $0.3 \pm 0.2$ & $0.3 \pm 0.1$ & $0.5 \pm 0.3$ & $0.5 \pm 0.3$ & $\begin{array}{l}0.9 \\
0.2\end{array}$ & $\begin{array}{l}\text { NS } \\
\text { NS }\end{array}$ \\
\hline
\end{tabular}

${ }^{a}$ Data presented are mean \pm SD.

${ }^{b} p<0.05$;

${ }^{c} p<$ 0.01; Subj. No. 1-8: Placebo $0.5 \mathrm{mg}-1 \mathrm{mg}$; Subj. No. 5: drop out; without Subj. No. 3; Subj. No. 9-20: Placebo $1.3 \mathrm{mg}-2 \mathrm{mg}$.

$d$ Pair comparisons (Fisher) if ANOVA significant.

\section{DISCUSSION}

The principal finding of this study is that SDZ ENA 713 induced a dose-dependent increase in the phasic component of REM sleep, REM density. The increase was by $50 \%$ in the first third and by $25 \%$ in the second third of the night. The threshold dose for this effect was 1 $\mathrm{mg}$, with a clear effect present at doses of $1.3 \mathrm{mg}$ and $2 \mathrm{mg}$. These are single doses that have been shown to be well tolerated in young and elderly human volunteers (Gray 1990). The effect was prolonged, persisting clearly for the first two-thirds of the night (Fig. 1). The long duration of action is in keeping with previous pharmacologic data in animals and man: in rat brain a single dose of SDZ ENA 713 inhibits AChE for at least 6 hours (Enz et al. 1989); in man, a single dose of SDZ ENA 713 inhibits plasma butyrylcholinesterase for at least 10 hours (Gray 1990).

Interestingly, REM sleep latency was not changed after any of the doses tested. The presence of an increase in REM density in the absence of a concomitant shortening of REM latency is different from the results ob- 


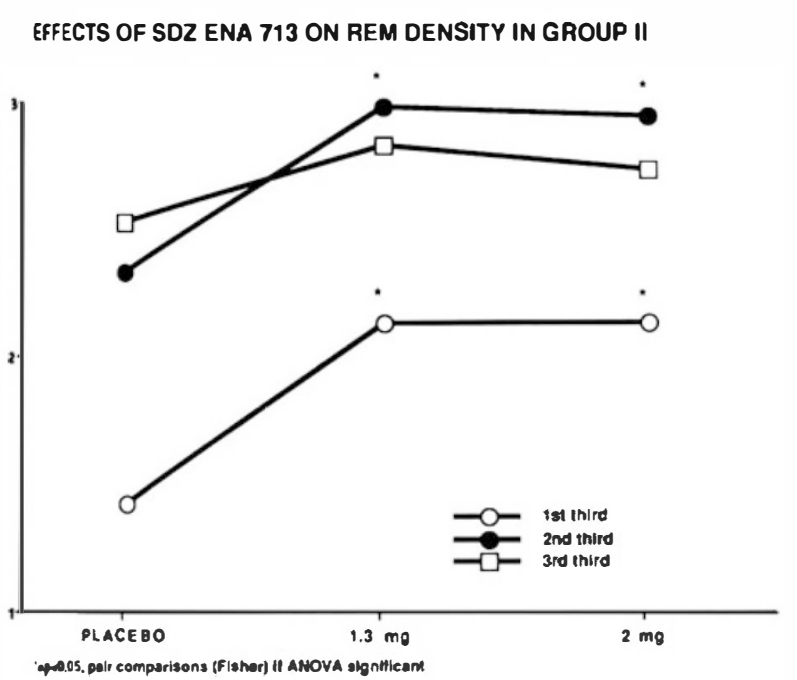

Figure 1. SDZENA 713 had a significant effect with increase in REM density after the $1.3 \mathrm{mg}$ and the $2 \mathrm{mg}$ dose in the first and second third of the night.

tained with other cholinergic drugs in normal volunteers, as shown in Table 3.

The reason for the absence of an effect of SDZ ENA 713 on REM latency in normal control subjects is not known. It may be that higher doses would have induced such a change, there is some evidence that REM density is a parameter generally more sensitive to drug effects than REMlatency (Pujol et al. 1975; JM Gaillard, personal communication). On the other hand, physostigmine and pilocarpine were reported to shorten REM latency, although REM density was not significantly affected by these compounds (Table 3 ).

An increase in REM density has been reported in depressed subjects after administration of the muscarinic agonist RS 86 (Lauer et al. 1989). A short REM latency and an increased REM density are typical features of the disturbed sleep in depression. It has been shown that increased REM density is a typical alteration of sleep found in young depressed patients, whereas shorter REM latencies only appear in depressed patients older than 40 years (Lauer et al. 1987). These changes in REM sleep in depression have been extensively discussed in the light of the cholinergic/aminergic reciprocal-interaction model of REMsleep regulation (Hobson et al. 1986). It has been hypothesized that the early appearance of the increased REM density in the sleep of younger depressed patients may be a first sign of a disturbed cholinergic/aminergic balance. Similarly the increase in REM density alone after SDZ ENA 713 may be the first sign of an increase in central cholinergic activity.

Rapid-eye movement density is suggested to be relatively independent of other parameters of REM sleep (Aserinsky 1969, 1973). According to the two-process model of sleep regulation, REM sleep depends on a circadian oscillator, process $C$, whereas slow-wave sleep is assumed to reflect process $S$, a sleep-dependent homeostatic process (Borbély 1982).

Aserinsky's observation that REM density is related to the amount of an individual's prior sleep has been corroborated in experiments in which subjects lived without time cues (Zimmermann et al. 1980). Slowwave sleep and REM density are assumed to be inversely related and may be under a similar control, since they are directly related to the timing of sleep rather than to an endogenous circadian oscillator. However, after SDZ ENA 713 no such tight coupling between REM density and slow-wave sleep was seen, REM density was increased in the presence of unchanged slowwave sleep. Furthermore the increase in REM density cannot be explained by prior sleep reduction, since all subjects slept well.

Alternatively it may be that SDZ ENA 713 tends to act selectively on structures controlling REM density rather than those affecting REM latency. Indeed, in the rat, SDZ ENA 713 has been shown to act preferentially on the hippocampus and cortex, rather than on the brain stem. It is tempting to speculate that the selective enhancing effect on REM density might reflect this hippocampal selectivity. However, the anatomy of the structures controlling REM density are poorly understood; if the hippocampus were involved, efferent pathways to the brain stem would have to be implicated, and so far, no such pathways are known. Nevertheless, in this regard it is of interest that Petsche

Table 3. Effects of Different Cholinomimetics on REM Sleep and Slow-Wave Sleep in Healthy Subjects (HS) and Depressed Patients (DP)

\begin{tabular}{lccccl}
\hline & & REM Density & REM Latency & SWS & \multicolumn{1}{c}{ References } \\
\hline SDZ ENA 713 & HS & $\uparrow$ & $\rightarrow$ & $\rightarrow$ & \\
Physostigmine & HS & $\rightarrow$ & $\downarrow$ & $\downarrow$ & Sitaram et al. 1976 \\
& DP & $\rightarrow$ & $\downarrow$ & $\downarrow$ & Berger et al. 1983 \\
Arecoline & HS & $\rightarrow$ & $\downarrow$ & $\rightarrow$ & Sitaram et al. 1978 \\
& DP & $\rightarrow$ & $\downarrow$ & $\rightarrow$ & Gillin et al. 1982 \\
RS 86 & HS & Not studied & $\downarrow$ & $\downarrow$ & Spiegel 1984 \\
& DP & $\uparrow$ & $\downarrow$ & $\downarrow$ & Lauer et al. 1989 \\
Pilocarpine & HS & $\rightarrow$ & $\downarrow$ & $\downarrow$ & Berkowitz et al. 1990 \\
\hline
\end{tabular}


et al. (1965) demonstrated the necessity of an intact pathway between midbrain reticular formation, septum, and hippocampus for the initiation of theta rhythms in the rabbit's hippocampus. Furthermore it has been demonstrated in animal studies that theta rhythm is involved in the encoding of memories during REM sleep (Winson 1990).

The finding of an increased REM density after the administration of SDZ ENA 713 is of more than academic interest. Rapid-eye movement sleep has been correlated with memory formation in animals (Smith 1985) and man (Koella 1985; De Koninck et al 1989; Smith et al 1991). In subjects with mental retardation, the most significant electrophysiologic index of cognitive competence was REM density (Feinberg et al. 1969). It is therefore possible that the increase in REM density might reflect not only a sign of central activity, but also a specific change in the activity of structures involved in the consolidation of memories.

In conclusion, SDZ ENA 713 is centrally active at well-tolerated doses in man, with a threshold dose of $1 \mathrm{mg}$, as evidenced by an increase in the density of REM sleep.

\section{REFERENCES}

Aserinsky E (1969): The maximal capacity for sleep: Rapid eye movement density as an index of sleep satiety. Biol Psychiatry 1:147-159

Aserinsky E (1973): Relationship of rapid eye movement density to the prior accumulation of sleep and wakefulness. Psychophysiology 10:545-558

Berger M, Lund R, Bronisch T, von Zerssen D (1983): REM latency in neurotic and endogenous depression and the cholinergic REM induction test. Psychiatry Res 10:113123

Berkowitz A, Sutton L, Janowsky DS, Gillin JC (1990): Pilocarpine, an orally active muscarinic cholinergic agonist, induces REM sleep and reduces delta sleep in normal volunteers. Psychiatry Res 33:113-119

Borbély AA (1982): A two process model of sleep regulation. Hum Neurobiol 1:195-204

De Koninck J, Lorrain D, Christ G, Proulx G, Coulombe D (1989): Intensive language learning and increases in rapid eye movement sleep: Evidence of a performance factor. Internatl J Psychophysiol 8:43-47

Enz A, Amstutz R, Hoffmann A, Gmelin G, Kelly PH (1989): Pharmacological properties of the preferentially centrally acting acetylcholinesterase inhibitor SDZ ENA 713. In Kewitz et al (eds), Pharmacological Interventions on Central Cholinergic Mechanisms in Senile Dementia. München, W. Zuckschwerdt Verlag

Feinberg I, Braun M, Shulman E (1969): EEG sleep patterns in mental retardation. Electroencephalogr Clin Neurophysiol 27:128-141
Gillin JC, Sitaram N, Mendelson WB (1982): Acetylcholine, sleep, and depression. Hum Neurobiol 1:211-219

Gray JA (1990): Investigator's brochure, SDZ ENA 713! senile dementia. Sandoz Document 703-513

Hobson JA, Lydic R, Baghdoyan HA (1986): Evolving concepts of sleep cycle generation: From brain centers to neuronal populations. Behav Brain Sci 9:371-488

Koella WP (1988): Die Physiologie des Schlafes: e. Einf. Stuttgart, Fischer, pp 125-127

Lauer C, Riemann D, Berger M (1987): Age, REM sleep, and depression. Sleep Res 16:283

Lauer C, Zulley J, Krieg JC, Riemann D, Berger M (1988): EEG sleep and the cholinergic REM induction test in anorexic and bulimic patients. Psychiatry Res 26: 171-181

Lauer C, Krieg JC, Zulley J, Riemann D, Berger M(1989): Det Schlaf bei Anorexia Nervosa, Bulimia Nervosa und depressiven Erkrankungen: Eine polysomnographische Vergleichsstudie. Fortschr Neurol Psychiat 57:403-410

Petsche H, Gogolak G, Van Zwieten PA (1965): Rhythmicity of septal cell discharges at various levels of reticular exc. tation. Electroencephalogr Clin Neurophysiol 19:25-33

Pujol J, Buda M (1975): Neurochemical approach of the sleep-waking cycle. In Lairy GC, Salzarulo P (eds), The Experimental Study of Human Sleep: Methodological problems. Paris, Elsevier, pp 87-94

Rechtschaffen A, Kales A (1968): A Manual of Standardized Terminology, Techniques and Scoring System for Sleep Stages of Human Subjects. Los Angeles, Brain Information Service/Brain Research Institute, University of California

Shiromani PJ, Gillin JC, Henriksen SJ (1987): Acetylcholine and the regulation of REM sleep: Basic mechanisms and clinical implications for affective illness and narcolepsy. Annu Rev Pharmacol Toxicol 27:137-156

Sitaram N, Wyatt RJ, Dawson S, Gillin JC (1976): REM sleep induction by physostigmine infusion during sleep. Science 191:1281-1283

Sitaram N, Moore AM, Gillin JC (1978): Experimental acceler. ation and slowing of REM sleep ultradion rhythm bo cholinergic agonist and antagonist. Nature 274:490-4\%

Smith C (1985): Sleep states and learning: A review of the animal literature. Neurosci Biobehav Rev 9:157-168

Smith C, Lapp L (1991): Increases in number of REMS and REM density in humans following an intensive learning period. Sleep 14:325-330

Spiegel R (1984): Effects of RS 86, an orally active cholinergix agonist, on sleep in man. Psychiatry Res 11:1-13

Velazquez-Moctezuma H, Gillin JC, Shiromani PJ (1991: Effect of specific M1, M2 muscarinic receptor agonists on REM sleep generation. Brain Res 503:128-131

Winson J (1990): The meaning of dreams. Sci Am 41-48

Zimmermann JC, Czeisler CA, Laxminarayan S, KnauerRG, Weitzman ED (1980): REM density is dissociated from REM sleep timing during free-running sleep episodes Sleep 2:409-415 